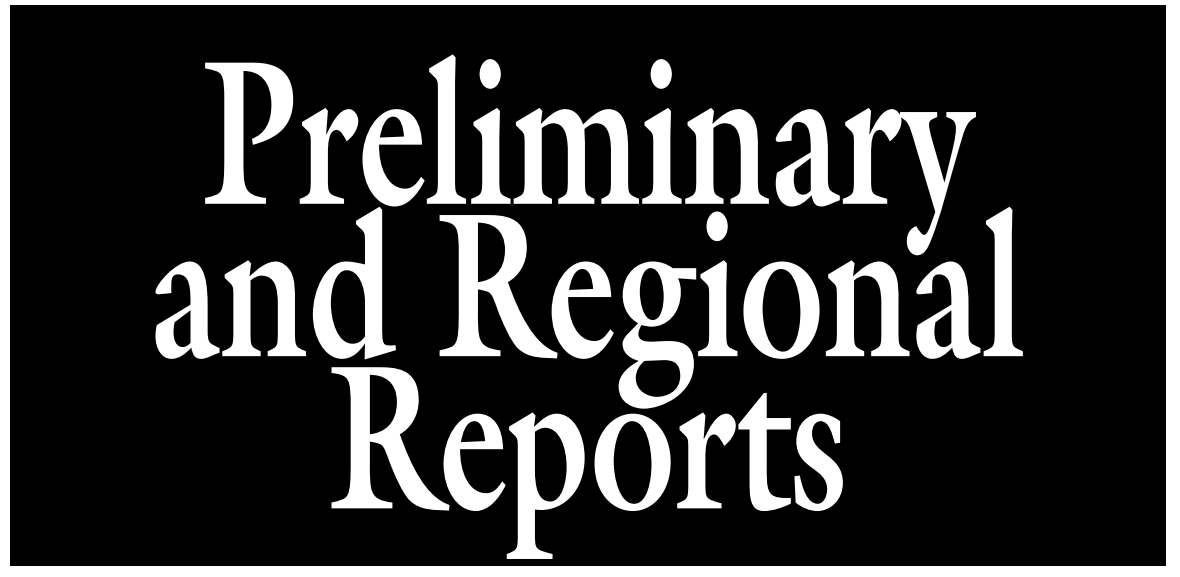

\title{
Effects of Different Culture Media on Growth and Proliferation of Dendrobium 'Earsakul' Protocorm-like Bodies
}

\author{
Piyada A. Tantasawat ${ }^{1}$, Apinya Khairum, Kitiya Arsakit, \\ Oythip Poolsawat, Paniti Pornbungkerd, and Chitpan Kativat
}

ADDITIONAL INDEX wORDs. 'Khai' banana, micropropagation, Musa acuminata AA group, orchid, PLB, tomato

SUMmARY. The effects of culture media on growth and proliferation of 'Earsakul' dendrobium (Dendrobium) protocorm-like bodies (PLBs) were evaluated in a twostep culture. After culturing on each of the four first step media for 4 months and on each of the four second step media for 4 months, the greatest total PLB fresh weight, increase in number of PLBs and growth rates were obtained when using Vacin and Went medium 1 (VW1) in both culture steps compared with those in 15 other medium combinations. Starting from $0.5 \mathrm{~g}$ of PLBs, culturing on VW1 for 8 months achieved a total of $415.25 \mathrm{~g}$ of PLBs, a multiplication rate of 830 -fold. The supplementation of tomato (Solanum lycopersicum) and substitution of 'Hom Thong' banana [Musa acuminata (AAA group)] with 'Khai' banana [M. acuminata (AA group)] in this new medium promoted growth and proliferation of dendrobium PLBs 2.4-fold over the control medium, suggesting its usefulness in commercial micropropagation.

$\mathrm{D}$ endrobium is one of the most popular ornamental and commercial orchids in Thailand, which is currently one of the world's largest producers and exporters (Hotrawaisaya et al., 2014). Various techniques are used to propagate dendrobium (e.g., division of clumps, cutting, separating of offshoots, and micropropagation). At

School of Crop Production Technology, Suranaree University of Technology, 111 University Avenue, Muang District, Nakhon Ratchasima 30000, Thailand

We thank Peter C. Bint for the critical reading of this manuscript. This research was supported by the Higher Education Research Promotion and National Research University Project of Thailand, Office of the Higher Education Commission, Ministry of Education, and grants from the Thailand Research Fund and Suranaree University of Technology, Thailand.

${ }^{1}$ Corresponding author. E-mail: piyada@sut.ac.th. present, micropropagation is often used commercially because it allows multiplication in large quantities (Puchooa, 2004). Dendrobium can be micropropagated via protocorms/ PLB; however, their slow growth and proliferation necessitate improvement of the culture procedure
(Teixeira da Silva, 2013a). Therefore, several plant growth regulators PGRs) such as benzyladenine (BA), adenine sulphate (AS), chitosan (CS), thidiazuron (TDZ), triacontanol (TRIA), as well as organic additives have been used as media supplements to stimulate in vitro growth and proliferation of several orchid species (Aktar et al., 2008; Bantawa et al., 2009; Islam et al., 2014; Latip et al., 2010; Malabadi et al., 2005; Nayak et al., 1997; Nge et al., 2006; Zhao et al., 2013). For example, Malabadi et al. (2005) found that TRIA can be used as an effective PGR in micropropagation of noble dendrobium (Dendrobium nobile) because it stimulated PLB formation. Similarly, using low concentrations of $\mathrm{BA}$ and TDZ also promoted the multiplication and development of gigantic phalaenopsis (Phalaenopsis gigantea) protocorms (Latip et al., 2010). For 'Earsakul' dendrobium, we also found that CS-promoted shoot and root growth of plantlets in vitro (Tantasawat et al., 2010). However, its effects on the younger plant stage (protocorms/PLBs) have not been evaluated.

In addition, several organic additives have also been supplemented to orchid media to promote their in vitro growth and proliferation (Chugh et al., 2009). Gnasekaran et al. (2010) evaluated the potential of papaya (Carica papaya), tomato, various cultivars of banana (Musa sp.) extracts, and coconut (Cocos nucifera) water for PLB proliferation in violet phalaenopsis ( $P$. violacea) and reported that 'Mas' banana pulp extract resulted in maximum growth of PLBs. Nevertheless, Nambiar et al. (2012) found that banana and tomato homogenate were not effective in improving the fresh weight of 'Alya Pink' dendrobium PLBs, while coconut water and glucose were most suitable for the PLB proliferation.

\begin{tabular}{llll}
\hline $\begin{array}{l}\text { Units } \\
\begin{array}{l}\text { To convert U.S. to SI, } \\
\text { multiply by }\end{array}\end{array}$ & U.S. unit & SI unit & $\begin{array}{l}\text { To convert SI to U.S., } \\
\text { multiply by }\end{array}$ \\
\hline 29.5735 & $\mathrm{fl} \mathrm{oz}$ & $\mathrm{mL}$ & 0.0338 \\
28.3495 & $\mathrm{oz}$ & $\mathrm{g}$ & 0.0353 \\
28,350 & $\mathrm{Oz}$ & $\mathrm{mg}$ & $3.5274 \times 10^{-5}$ \\
1 & $\mathrm{ppb}$ & $\mu \mathrm{g} \cdot \mathrm{L}^{-1}$ & 1 \\
0.001 & $\mathrm{ppm}$ & $\mathrm{g} \cdot \mathrm{L}^{-1}$ & 1000 \\
1 & $\mathrm{ppm}$ & $\mathrm{mg} \cdot \mathrm{L}^{-1}$ & 1 \\
0.001 & $\mathrm{ppm}$ & $\mathrm{mL} \cdot \mathrm{L}^{-1}$ & 1000 \\
6.8948 & $\mathrm{psi}$ & $\mathrm{kPa}$ & 0.1450 \\
$\left({ }^{\circ} \mathrm{F}-32\right) \div 1.8$ & ${ }^{\circ} \mathrm{F}$ & ${ }^{\circ} \mathrm{C}$ & $\left({ }^{\circ} \mathrm{C} \times 1.8\right)+32$
\end{tabular}

Horllechnology · October 2015 25(5) 
These results suggest that the effects of organic additives may vary depending on orchid genotypes as well as developmental stages and need to be determined individually. Differential effects of Malaysian banana genotypes on orchid PLB growth and proliferation were also observed (Gnasekaran et al., 2010; Nambiar et al., 2012); however, the genotypic effects of thai banana on dendrobium PLBs have not been evaluated.

This study aimed to evaluate the potential effects of various culture media varying in basal salts, PGRs, and organic additives on the growth and proliferation of 'Earsakul' dendrobium PLBs during 8 months of two-step culture in vitro.

\section{Materials and methods}

Plant material and in vitro CUlture. Protocorm-like bodies of 'Earsakul' dendrobium were used as starting materials to study the potential of various culture media for promoting growth and proliferation. The PLBs were cultured in two steps (4 months for each step) to allow the development of vigorous PLBs in the first step before the evaluation of CS effects in the second step [we previously found that $C S$-stimulated proliferation of vigorous rhynchostylis (Rhynchostylis sp.) PLBs but had negative effects on the weak ones (P.A. Tantasawat, unpublished data)]. Four culture media [three modified VW (Vacin and Went, 1949) media and one modified Murashige and Skoog (MS) (Murashige and Skoog, 1962) medium] were used in the first step culture: 1) Vacin and Went medium 0 (VW0), VW basal salts, 100 $\mathrm{g} \cdot \mathrm{L}^{-1}$ potato (Solanum tuberosum), $200 \mathrm{~mL} \cdot \mathrm{L}^{-1}$ coconut water, $50 \mathrm{~g} \cdot \mathrm{L}^{-1}$ 'Hom Thong' banana, 2\% (w/v) sucrose, $0.2 \%(\mathrm{w} / \mathrm{v})$ activated charcoal, and $0.7 \%(\mathrm{w} / \mathrm{v})$ granulated agar, $\mathrm{pH}$ 5.0 (control; the popular medium frequently used for orchid micropropagation in Thailand; Tantasawat and Waranyuwat, 2008); 2) VWl, similar to VW0 but with the supplementation of $50 \mathrm{~g} \cdot \mathrm{L}^{-1}$ tomato and the substitution of 'Hom Thong' banana with 'Khai' banana; 3) Vacin and Went medium 2 (VW2), similar to VWI but with the supplementation of $2 \mu \mathrm{g} \cdot \mathrm{L}^{-1}$ TRIA; and 4) Murashige and Skoog medium 2 (MS2), MS basal salts, $2.3 \mu \mathrm{g} \cdot \mathrm{L}^{-1} \mathrm{TDZ}$, $1 \mathrm{mg} \cdot \mathrm{L}^{-1} \mathrm{AS}, 200 \mathrm{~mL} \cdot \mathrm{L}^{-1}$ coconut water, $2 \%(\mathrm{w} / \mathrm{v})$ sucrose, and $0.2 \%$ $(\mathrm{w} / \mathrm{v})$ gelrite agar, $\mathrm{pH}$ 5.5.

Four culture media (three modified VW media and one modified MS medium) were used in the second step culture: 1) VW0; 2) VWl; 3) Vacin and Went medium 5 (VW5), similar to VWl but with the supplementation of $50 \mathrm{mg} \cdot \mathrm{L}^{-1} \mathrm{CS}$; and 4) Murashige and Skoog medium 3 (MS3), similar to MS2 but with the supplementation of $50 \mathrm{mg} \cdot \mathrm{L}^{-1} \mathrm{CS}$. Before use, all media were sterilized by autoclaving at $121{ }^{\circ} \mathrm{C}, 115 \mathrm{kPa}$ for $20 \mathrm{~min}$. Protocorm-like bodies $(0.5 \mathrm{~g})$ were randomly placed into an 8 - $\mathrm{fl} \mathrm{oz}$ culture bottle containing one of the first step media. The cultures were maintained in a culture room at $27 \pm$ $2{ }^{\circ} \mathrm{C}$ with a 16-h photoperiod provided by cool-white fluorescent tubes at a photosynthetically active radiation of $100 \mu \mathrm{mol} \cdot \mathrm{m}^{-2} \cdot \mathrm{s}^{-1}$ for 4 months. Subculturing of PLBs was performed monthly. After 4 months, $0.5 \mathrm{~g}$ each of PLBs from the first step medium was transferred onto the second step medium in an 8-fl oz culture bottle. Cultures were maintained in the same conditions as for the first step for 4 months. The length of the study with both steps was 8 months.

MEASUREMENT OF GROWTH AND PROLIFERATION. Growth and proliferation parameters (total PLB fresh weight, number of PLBs, fresh weight per PLB, and growth rates) were measured after 2 and 4 months of culture in the first and second step media. Fresh weight per PLB was obtained from the mean of 10 randomly chosen PLBs from each replication. Growth rate at each stage was calculated as total PLB fresh weight at the end of the stage- total PLB fresh weight at the beginning of the stage divided by the number of months. The number of PLB increase (fold) was calculated from the total number of PLBs at 2 or 4 months of culture on the second step media divided by the number of PLBs at the beginning of the second step culture. All measurements were performed under aseptic condition in a laminar flow cabinet.

EXPERIMENTAL DESIGN AND STATISTICAL ANALYSIS. A completely randomized design was conducted with 17 replications. Each replication consisted of PLBs cultured in an 8-fl $\mathrm{Oz}$ culture bottle. At the first step culture, 4 first step media (VW0,
VW1, VW2, and MS2) were evaluated for effects on growth and proliferation using 15 randomly chosen replications/medium. At the second step culture, 4 second step media (VW0, VWl, VW5, and MS3) were used, and 16 combinations of first and second step media were evaluated for effects on growth and proliferation using 15 randomly chosen replications/medium combination. One-way analysis of variance and Duncan's multiple range test were used to evaluate the effects of various culture media on 'Earsakul' dendrobium growth and proliferation using SPSS (version 14.0; IBM Corp., Armonk, NY).

\section{Results and discussion}

After PLBs were cultured on four different first step media for 2 months, the effects of the first step media were highly significant $(P<0.01)$ on total PLB fresh weight, number of PLBs, fresh weight per PLB, and growth rates (Table 1). At 4 months, these growth and proliferation parameters except PLB numbers also differed significantly $(P<0.01)$ among the first step media. Most parameters in VW0 (control), VWl, and VW2 media were significantly higher than those in MS2 at the end of 2 and 4 months on the first step media, possibly resulting from supplementing with several organic additives, especially banana, in these media. Homogenized banana fruit (or banana pulp extract/powder) is often reported to promote orchid (violet phalaenopsis and dendrobium) growth (Gnasekaran et al., 2010; Nambiar et al., 2012; Puchooa, 2004). The stimulative effect could be due to its ability to stabilize the $\mathrm{pH}$ of the medium (Molnár et al., 2011; Thorpe et al., 2008). In addition, some cytokinins and/or their derivatives (e.g., zeatin), phenolic compounds, dopamine, $\beta$-carotene, flavonoids, vitamins, and minerals are present in banana pulp (Anyasi et al., 2013; Ge et al., 2008; Mohapatra et al., 2010). These PGRs, nutrition, and/or antioxidants may play a major role in promoting orchid protocorm/PLB growth and proliferation (Chen et al., 2002; Gnasekaran et al., 2010; Teixeira da Silva, 2013a). It has also been suggested that antioxidants may not affect the growth and development of 
orchid PLBs directly, but reduce tissue or medium browning (Teixeira da Silva, 2013b).

At 2 and 4 months of culture in VW0 and VWl, the total fresh weight and growth rates of PLBs were greatest. No significant difference existed between the two media on these parameters. However, PLBs were significantly larger (1.7- to 2.0-fold greater fresh weight per PLB) in VWl than VW0, which may due to the effects of tomato and/or 'Khai' banana. At 2 months, VW0 induced the greatest PLB numbers but at 4 months, PLB numbers among the four media did not significantly differ $(P>0.05)$ (Table 1$)$. Interestingly, the addition of $2 \mu \mathrm{g} \cdot \mathrm{L}^{-1}$ TRIA in the first step medium (VW2) did not provide a beneficial effect over VWl. Instead, it appeared to slightly suppress the PLB growth and proliferation. By contrast, Malabadi et al. (2005) found that low concentrations $(2,4$, and 7 $\left.\mu \mathrm{g} \cdot \mathrm{L}^{-1}\right)$ of TRIA-promoted initiation of PLBs in noble dendrobium, whereas at higher concentrations (10-30 $\left.\mu \mathrm{g} \cdot \mathrm{L}^{-1}\right)$, it failed to promote PLBs. These results suggest that the TRIA response appears to be genotype specific.

After 2 and 4 months of culture in the second step media, the differences among media of most growth and proliferation parameters were highly significant $(P<0.01)$ (Tables 2 and 3$)$. When these 16 medium combinations were evaluated after 2 months on the second step media, PLBs transferred from VW0 onto VW0 and from VWl onto MS3 had the greatest total fresh weight $(6.83$ and $5.99 \mathrm{~g}$, respectively) and growth rates (3.17 and $2.74 \mathrm{~g} /$ month, respectively). However, the maximum increase in the number of PLBs was obtained from PLBs initiated on VWl and transferred to VWl (34.21-fold) and from PLBs initiated on VWl and transferred to MS3 (32.79-fold), which were significantly greater than that of control (VW0 and transferred to VW0; 14.30-fold) (Table 2).

After 4 months of culture on the second step media, it was found that PLBs cultured on VWl and transferred to VWl induced the highest total PLB fresh weight $(25.76 \mathrm{~g})$, the largest increase in number of PLBs (113.49-fold), and the most rapid growth rate of $10.29 \mathrm{~g} /$ month, significantly greater than those of PLBs cultured on other medium combinations $(P<0.05)$. In addition, the size of PLBs on this medium combination

Table 1. The effects of the first step media on growth and proliferation of 'Earsakul' dendrobium protocorm-like bodies (PLBs) at 2 and 4 mo. after culturing on the first step media.

\begin{tabular}{|c|c|c|c|c|c|c|c|c|}
\hline \multirow[b]{2}{*}{$\begin{array}{l}\text { First step } \\
\text { media }^{z}\end{array}$} & \multicolumn{4}{|c|}{$2 \mathrm{mo}}$. & \multicolumn{4}{|c|}{$4 \mathrm{mo}}$. \\
\hline & $\begin{array}{l}\text { Total fresh wt } \\
\text { of PLBs }(g)^{y}\end{array}$ & PLBs (no.) & $\begin{array}{c}\text { Fresh wt } \\
(\mathrm{mg} / \mathrm{PLB})^{\mathrm{y}}\end{array}$ & $\begin{array}{c}\text { Growth } \\
\text { rate }(\mathrm{g} / \mathrm{mo} .)\end{array}$ & $\begin{array}{c}\text { Total fresh } \\
\text { wt of PLBs }(g)\end{array}$ & PLBs (no.) & $\begin{array}{c}\text { Fresh wt } \\
(\mathrm{mg} / \text { PLB })\end{array}$ & $\begin{array}{c}\text { Growth } \\
\text { rate }(\mathrm{g} / \mathrm{mo} .)\end{array}$ \\
\hline VW0 & $1.87 \mathrm{a}^{\mathrm{x}}$ & $261.52 \mathrm{a}$ & $7.23 \mathrm{c}$ & $0.69 \mathrm{a}$ & $6.04 \mathrm{a}$ & 599.62 & $10.75 \mathrm{~b}$ & $2.11 \mathrm{a}$ \\
\hline VWl & $1.95 \mathrm{a}$ & $135.16 \mathrm{~b}$ & $14.50 \mathrm{a}$ & $0.72 \mathrm{a}$ & $8.06 \mathrm{a}$ & 472.31 & $18.22 \mathrm{a}$ & $3.11 \mathrm{a}$ \\
\hline VW2 & $1.37 \mathrm{~b}$ & $157.46 \mathrm{~b}$ & $9.00 \mathrm{~b}$ & $0.43 \mathrm{~b}$ & $6.81 \mathrm{a}$ & 583.59 & $11.77 \mathrm{~b}$ & $2.74 \mathrm{a}$ \\
\hline MS2 & $0.51 \mathrm{c}$ & $80.00 \mathrm{c}$ & $7.09 \mathrm{c}$ & $0.01 \mathrm{c}$ & $2.74 \mathrm{~b}$ & 395.20 & $7.00 \mathrm{c}$ & $1.12 \mathrm{~b}$ \\
\hline
\end{tabular}

${ }^{2} \mathrm{VW} 0=$ Vacin and Went medium $0 ; \mathrm{VWl}=$ Vacin and Went medium 1; VW2 = Vacin and Went medium 2; MS2 = Murashige and Skoog medium 2.

${ }^{\mathrm{y}} \mathrm{l} \mathrm{g}=0.0353 \mathrm{oz} ; \mathrm{l} \mathrm{mg}=3.5274 \times 10^{-5} \mathrm{oz}$.

'Means in the same column with different letters are significantly different $(P<0.05)$ based on Duncan's multiple range test.

Table 2. Effects of the first and second step media on growth and proliferation of 'Earsakul' dendrobium protocorm-like bodies (PLBs) at 2 mo. after culturing on the second step media.

\begin{tabular}{|c|c|c|c|c|c|}
\hline $\begin{array}{l}\text { First step } \\
\text { media }^{z}\end{array}$ & $\begin{array}{c}\text { Second } \\
\text { step media } \\
\end{array}$ & $\begin{array}{c}\text { Total fresh } \\
\text { wt of PLBs }(g)^{y}\end{array}$ & PLB increase (folds) & Fresh wt $(\mathrm{mg} / \mathrm{PLB})^{\mathrm{y}}$ & Growth rate $(\mathrm{g} / \mathrm{mo})$. \\
\hline \multirow[t]{3}{*}{ VW0 } & VW0 & $6.83 \mathrm{a}^{\mathrm{x}}$ & $14.30 \mathrm{~cd}$ & $10.33 \mathrm{ab}$ & $3.17 \mathrm{a}$ \\
\hline & VWl & $4.19 \mathrm{cde}$ & $10.78 \mathrm{cde}$ & $8.86 \mathrm{a}-\mathrm{d}$ & $1.84 \mathrm{cde}$ \\
\hline & MS3 & 4.44 cde & 9.65 cde & $11.08 \mathrm{a}$ & $1.97 \mathrm{cde}$ \\
\hline \multirow[t]{2}{*}{ VWl } & VW0 & $4.62 \mathrm{~cd}$ & $24.80 \mathrm{~b}$ & $7.30 \mathrm{bcd}$ & $2.06 \mathrm{~cd}$ \\
\hline & MS3 & $5.99 \mathrm{ab}$ & 32.79 a & $6.83 \mathrm{bcd}$ & $2.74 \mathrm{ab}$ \\
\hline \multirow[t]{4}{*}{ VW2 } & VW0 & $3.17 \mathrm{efg}$ & $9.83 \mathrm{cde}$ & $8.11 \mathrm{a}-\mathrm{d}$ & $1.33 \mathrm{efg}$ \\
\hline & VWl & $3.47 \mathrm{def}$ & $8.34 \mathrm{de}$ & $10.93 \mathrm{a}$ & $1.49 \mathrm{def}$ \\
\hline & VW5 & $2.35 \mathrm{fgh}$ & $6.48 \mathrm{de}$ & $9.33 \mathrm{abc}$ & $0.92 \mathrm{fgh}$ \\
\hline & MS3 & $3.47 \mathrm{def}$ & $9.93 \mathrm{cde}$ & $8.87 \mathrm{a}-\mathrm{d}$ & $1.49 \mathrm{def}$ \\
\hline MS2 & VW0 & $2.21 \mathrm{fgh}$ & $4.85 \mathrm{e}$ & $6.70 \mathrm{~cd}$ & $0.85 \mathrm{fgh}$ \\
\hline$P$ value & & $<0.001$ & $<0.001$ & 0.001 & $<0.001$ \\
\hline
\end{tabular}

${ }^{2}$ VW0 = Vacin and Went medium 0; VW1 = Vacin and Went medium 1; VW2 = Vacin and Went medium 2; VW5 = Vacin and Went medium 5; MS2 = Murashige and Skoog medium 2; MS3 = Murashige and Skoog medium 3.

${ }^{\mathrm{y}} \mathrm{lg}=0.0353 \mathrm{oz} ; \mathrm{l} \mathrm{mg}=3.5274 \times 10^{-5} \mathrm{oz}$.

${ }^{x}$ Means in the same column with different letters are significantly different $(P<0.05)$ based on Duncan's multiple range test. 
was comparable to those cultured on other medium combinations $[P>$ 0.05 (Table 3)]. These results suggest that both first and second step media significantly influence PLB growth and proliferation of 'Earsakul' dendrobium. If we consider total PLB fresh weight obtained from culturing $0.5 \mathrm{~g}$ PLBs at the beginning of the experiment $(0$ month $)$ until the end of experiment (8 months), the growth and proliferation (as suggested by total PLB fresh weight obtained at the end of the experiment) clearly varied among the media, especially at 8 months. Culturing on VWl for 8 months achieved a total of $415.25 \mathrm{~g}$ of PLBs with a multiplication rate of 830 -fold (Fig. 1). On this medium, the total PLB fresh weight at 8 months was 2.4-fold greater than those cultured on the control medium, which would be very useful for future commercial applications. Moreover, most PLBs cultured on VWl were green and vigorous.

The VWl medium contained VW basal salts and several organic additives including $100 \mathrm{~g} \cdot \mathrm{L}^{-1}$ potato, $200 \mathrm{~mL} \cdot \mathrm{L}^{-1}$ coconut water, $50 \mathrm{~g} \cdot \mathrm{L}^{-1}$ each of 'Khai' banana (AA group) and tomato without any PGRs. It was different from VW0 in that it used 'Khai' banana instead of 'Hom Thong' banana (AAA group) and it

Table 3. Effects of the first and second step media on growth and proliferation of 'Earsakul' dendrobium protocorm-like bodies (PLBs) at 4 mo. after culturing on the second step media.

\begin{tabular}{|c|c|c|c|c|c|}
\hline $\begin{array}{l}\text { First } \\
\text { step media }{ }^{z}\end{array}$ & $\begin{array}{c}\text { Second } \\
\text { step media }\end{array}$ & $\begin{array}{c}\text { Total fresh } \\
\text { wt of PLBs }(\mathrm{g})^{\mathrm{y}}\end{array}$ & PLB increase (folds) & Fresh wt $(\mathrm{mg} / \mathrm{PLB})^{\mathrm{y}}$ & Growth rates (g/mo.) \\
\hline \multirow[t]{4}{*}{ VW0 } & VW0 & $14.65 \mathrm{bcd}^{\mathrm{x}}$ & $46.12 \mathrm{c}-\mathrm{f}$ & 6.78 & $3.91 \mathrm{bc}$ \\
\hline & VWl & $16.18 \mathrm{bc}$ & $48.49 \mathrm{c}-\mathrm{f}$ & 7.11 & $6.00 \mathrm{~b}$ \\
\hline & VW5 & $12.25 \mathrm{bcd}$ & $30.21 \mathrm{e}-\mathrm{h}$ & 8.86 & $4.89 \mathrm{~b}$ \\
\hline & MS3 & $18.02 \mathrm{~b}$ & $52.70 \mathrm{cde}$ & 6.92 & $6.79 \mathrm{~b}$ \\
\hline \multirow[t]{2}{*}{ VW1 } & VW0 & $14.72 \mathrm{bcd}$ & $68.35 \mathrm{bc}$ & 8.00 & $5.05 \mathrm{~b}$ \\
\hline & MS3 & $17.97 \mathrm{~b}$ & $76.81 \mathrm{~b}$ & 7.78 & $5.99 \mathrm{~b}$ \\
\hline \multirow[t]{4}{*}{ VW2 } & VW0 & $11.70 \mathrm{~cd}$ & $33.17 \mathrm{efg}$ & 8.50 & $4.27 \mathrm{bc}$ \\
\hline & VWl & $11.90 \mathrm{bcd}$ & $32.64 \mathrm{efg}$ & 10.20 & $4.21 \mathrm{bc}$ \\
\hline & VW5 & $8.76 \mathrm{~d}$ & $24.15 \mathrm{fgh}$ & 8.14 & $3.63 \mathrm{bc}$ \\
\hline & MS3 & $12.70 \mathrm{bcd}$ & $42.34 \mathrm{~d}-\mathrm{g}$ & 7.46 & $4.61 \mathrm{~b}$ \\
\hline MS2 & VW0 & $10.88 \mathrm{~cd}$ & $18.48 \mathrm{gh}$ & 8.75 & $4.34 \mathrm{bc}$ \\
\hline$P$ value & & $<0.001$ & $<0.001$ & 0.109 & $<0.001$ \\
\hline
\end{tabular}

${ }^{2} \mathrm{VW0}=$ Vacin and Went medium 0; VWl = Vacin and Went medium 1; VW2 = Vacin and Went medium 2; VW5 = Vacin and Went medium 5; MS2 = Murashige and Skoog medium 2; MS3 = Murashige and Skoog medium 3.

${ }^{\mathrm{y}} \mathrm{lg}=0.0353 \mathrm{oz} ; \mathrm{l} \mathrm{mg}=3.5274 \times 10^{-5} \mathrm{oz}$.

'Means in the same column with different letters are significantly different $(P<0.05)$ based on Duncan's multiple range test.

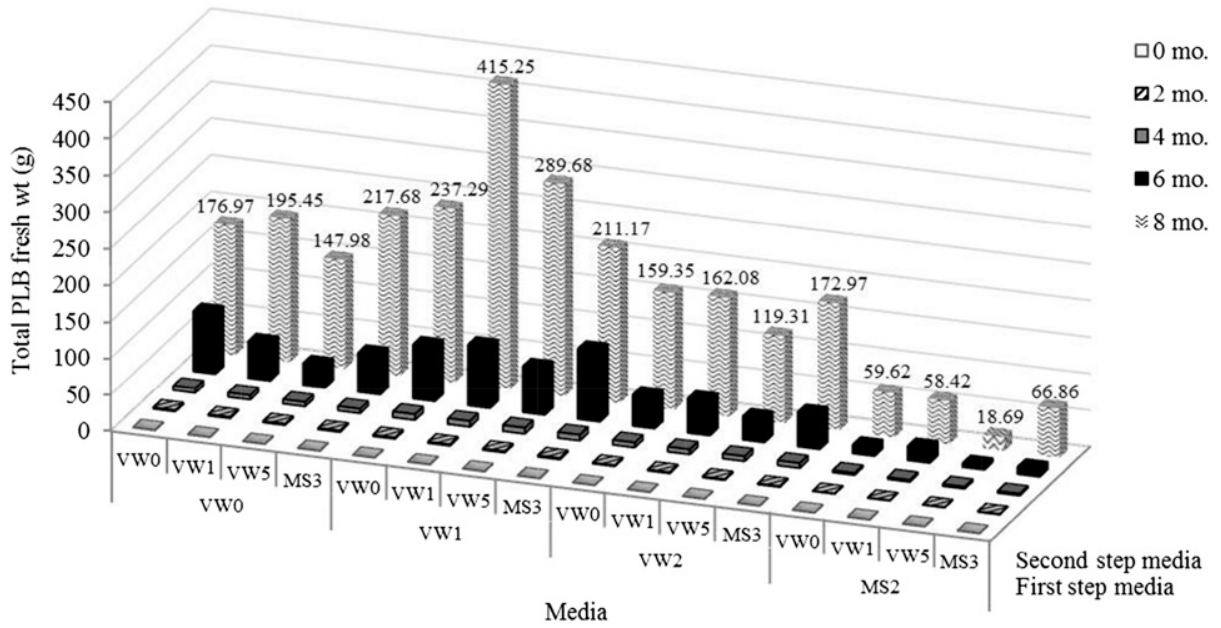

Fig. 1. Effects of different first step and second step culture media on total protocorm-like body (PLB) fresh weight of 'Earsakul' dendrobium after culturing for $0,2,4,6$, and 8 months (mo.); VW0 = Vacin and Went medium 0; VWl = Vacin and Went medium 1; VW2 = Vacin and Went medium 2; VW5 = Vacin and Went medium 5; MS2 = Murashige and Skoog medium 2; MS3 = Murashige and Skoog medium 3; $1 \mathrm{~g}=0.0353 \mathrm{oz}$. 
also contained tomato. In our preliminary work, when tomato was not included in the VWl medium, PLB growth and proliferation was also better than VW0, suggesting the beneficial effect of 'Khai' banana. Differential responses from supplementing culture media with various banana genotypes were also observed by Gnasekaran et al. (2010) who reported that the addition of $10 \%$ (w/v) 'Mas' banana (AA group) into half MS medium promoted maximum PLB proliferation rate $(80 \%)$ in violet phalaenopsis when compared with the addition of 'Rastali' banana [M. ×paradisiaca (AAB group)], 'Berangan' banana $[M$. sapientum (AAA group)], and 'Grand Naine' banana [M. acuminata (AAA group)] (40\%, 50\%, and 40\%, respectively). Similarly, Nambiar et al. (2012) found that on the medium containing 'Emas' banana [M. acuminata (AA group)], the PLB fresh weight of 'Alya Pink' dendrobium was greater than those containing commercial banana powder (Sigma-Aldrich, St. Louis, MO) and other types of local banana homogenate ['Berangan' banana and 'Tanduk' banana $[M$. $\times$ paradisiaca (AAB group)]\}. However, neither types of banana homogenate resulted in greater growth compared with controls (medium without organic additives). These results suggest that the AA group banana may have greater growthpromoting effects than other groups. Moreover, the effects of banana supplementation on orchid PLBs appear to be genotype dependent and should be determined individually for each orchid genotype.

Sripathumrak (2004) reported that pulp of 'Khai' banana contained more sucrose than that of 'Hom' banana [M. acuminata (AAA Group)] at all ripening stages. Sucrose has been shown to be the most suitable source of carbon and energy for plant cultures and may have the ability to induce embryogenesis (Thorpe et al., 2008; Tokuhara and Mii, 2003). In dendrobium, the addition of sucrose resulted in greater PLB fresh weight and increased total chlorophyll content compared with other types of sugar (Nambiar et al., 2012). Furthermore, several researchers found that 'Khai' banana pulp (or banana flour) had higher amounts of antioxidant compounds (ascorbic acid, phenolic, and carotenoid content), antioxidant capacity, and activities than 'Hom Thong' banana (Amorim et al., 2009; Fernando et al., 2014; Sittisuanjik and Sriruksa, 2013). Sugar and antioxidants play an integral role in proliferation of healthy PLBs. Furthermore, the presence of antioxidants can also prevent browning of PLB culture (Gnasekaran et al., 2012). It is interesting to note that 'Khai' banana is cheaper than 'Hom Thong' banana in Thailand, which will help reduce the cost of micropropagation. The use of organic additives instead of PGRs also makes this medium very cost-effective for commercial application.

The addition of tomato may further enhance PLB growth and proliferation and promote the formation of green and vigorous PLBs. Gnasekaran et al. (2012) also reported that VW medium supplemented with $20 \%(\mathrm{w} / \mathrm{v})$ tomato gave a better response in 'Kasem's Delight' vanda [Vanda sp. (green and vigorous protocorms)]. Similarly, VW medium containing $5 \%(\mathrm{w} / \mathrm{v})$ tomato was observed to give denser and greener protocorms of nodding swamp orchid [Geodorum densiflorum (Muthukrishnan et al., 2013)]. These results demonstrate that tomato may enhance the growth and development of protocorms, possibly through lycopene, an acyclic carotenoid, which provides the best protection for cell damage and reduces the occurrence of culture browning (Gnasekaran et al., 2012; Halliwell, 1996; Marković et al., 2006).

Although we found that the supplementation of CS $\left(50 \mathrm{mg} \cdot \mathrm{L}^{-1}\right)$ promoted shoot and root growth of 'Earsakul' dendrobium at the plantlet stage (Tantasawat et al., 2010), adding the same concentration of CS (VW5) at the PLB stage significantly reduced the PLB proliferation, suggesting that the CS effect is developmental stage dependent, and optimal concentrations of CS should be identified for specific developmental stages.

In conclusion, VWl is the best culture medium for micropropagation of 'Earsakul' dendrobium PLBs. Interestingly, this medium is also optimal for other orchids such as rhynchostylis, suggesting its wider application (P.A. Tantasawat, unpublished data). In addition, the simplicity and low cost of this medium make it very attractive for commercial micropropagation.

\section{Literature cited}

Aktar, S., K.M. Nasiruddin, and K. Hossain. 2008. Effects of different media and organic additives interaction on in vitro regeneration of Dendrobium orchid. J. Agr. Rural Dev. 6:69-74.

Amorim, E.P., A.D. Vilarinhos, K.O. Cohen, V.B.O. Amorim, J.A. dos SantosSerejo, S. Oliveira e Silva, K.N. Pestana, V.J. dos Santos, N.S. Paes, D.C. Monte, and R.V. dos Reis. 2009. Genetic diversity of carotenoid-rich bananas evaluated by diversity arrays technology (DArT). Genet. Mol. Biol. 32:96-103.

Anyasi, T.A., A.I.O. Jideani, and G.R.A. Mchau. 2013. Functional properties and postharvest utilization of commercial and noncommercial banana cultivars. Comprehensive Rev. Food Sci. Food Safety 12:509-522.

Bantawa, P., O.S. Roy, P. Ghosh, and T.K. Mondal. 2009. Effect of bavistin and adenine sulphate on in vitro shoot multiplication of Picrorbiza scrophularifflora Pennell.: An endangered medicinal plant of Indo-China Himalayan regions. Plant Tissue Cult. Biotechnol. 19:237-245.

Chen, L.-R., J.-T. Chen, and W.-C. Chang. 2002. Efficient production of protocorm-like bodies and plant regeneration from flower stalk explants of sympodial orchid Epidendrum radicans. In Vitro Cell. Dev. Biol. Plant 38:441-445.

Chugh, S., S. Guha, and I.U. Rao. 2009. Micropropagation of orchids: A review on the potential of different explants. Sci. Hort. 122:507-520.

Fernando, H.R.P., V. Srilaong, N. Pongprasert, P. Boonyaritthongchai, and P. Jitareerat. 2014. Changes in antioxidant properties and chemical composition during ripening in banana variety 'Hom Thong' (AAA group) and 'Khai' (AA group). Intl. Food Res. J. 21:749-754.

Ge, L., S.N. Tan, J.W.H. Yong, L. Hua, and E.S. Ong. 2008. Separation of cytokinin isomers with a partial fillingmicellar electrokinetic chromatographymass spectrometry approach. Electrophoresis 29:2024-2032.

Gnasekaran, P., X. Rathinam, U.R. Sinniah, and S. Subramaniam. 2010. A study on the use of organic additives on the protocorm-like bodies (PLBS) growth of Phalaenopsis violacea orchid. J. Phytol. 2:29-33.

Gnasekaran, P., R. Poobathy, M. Mahmood, M.R. Samian, and S. Subramaniam. 2012. Effects of complex organic additives on 
improving the growth of PLBs of Vanda Kasem's Delight. Austral. J. Crop Sci. 6:1245-1248.

Halliwell, B. 1996. Antioxidants, p. 596603. In: E.E. Ziegler and L.J. Filer (eds.). Present knowledge in nutrition. 7th ed. Intl. Life Sci. Inst. Press, Washington, DC.

Hotrawaisaya, C., W. Chandraprakaikul, and N. Suthikarnarunai. 2014. Performance improvement by logistics collaboration management model for orchid flower industry in Thailand. Eng. Mgt. Res. 3:52-68.

Islam, M.N., K.M. Nasiruddin, and M. Al-Amin. 2014. In vitro growth and multiplication of a hybrid orchid (Dendrobium alba $\times$ Ascanda dongtarm) with different concentration of plant growth regulators. J. Biosci. Agr. Res. 1:27-33.

Latip, M.A., R. Murdad, Z.A. Aziz, L.H. Ting, L.M. Govindasamy, and R. Ripin. 2010. Effects of $\mathrm{N}^{6}$-benzyladenine and thidiazuron on proliferation of Phalaenopsis gigantea protocorms. Asia Pac. J. Mol. Biol. Biotechnol. 18:217-220.

Malabadi, R.B., G.S. Mulgund, and N. Kallappa. 2005. Micropropagation of Dendrobium nobile from shoot tip sections. J. Plant Physiol. 162:473-478.

Marković, K., M. Hruškar, and N. Vahčić. 2006. Lycopene content of tomato products and their contribution to the lycopene intake of Croatians. Nutr. Res. 26:556-560.

Mohapatra, D., S. Mishra, and N. Sutar. 2010. Banana and its by-product utilization: An overview. J. Sci. Ind. Res. 69:323-329.

Molnár, Z., E. Virág, and V. Ördög. 2011. Natural substances in tissue culture media of higher plants. Acta Biologica Szegediensis 55:123-127.
Murashige, T. and F. Skoog. 1962. A revised medium for rapid growth and bioassays with tobacco tissue cultures. Physiol. Plant. 15:473-497.

Muthukrishnan, S., T.S. Kumar, and M.V. Rao. 2013. Effects of different media and organic additives on seed germination of Geodorum densiflorum (Lam) Schltr.-An endangered orchid. Indian J. Soc. Res. 2:23-26.

Nambiar, N., C.S. Tee, and M. Maziah. 2012. Effects of organic additives and different carbohydrate sources on proliferation of protocorm-like bodies in Dendrobium Alya Pink. Plant Omics J. 5:10-18.

Nayak, N.R., S.P. Rath, and S. Patnaik. 1997. In vitro propagation of three epiphytic orchids, Cymbidium aloifolium (L.) Sw., Dendrobium apbyllum (Roxb.) Fisch. and Dendrobium moschatum (Buch-Ham) Sw. through thidiazuroninduced high frequency shoot proliferation. Sci. Hort. 71:243-250.

Nge, K.L., N. Nwe, S. Chandrkrachang, and W.F. Stevens. 2006. Chitosan as a growth stimulator in orchid tissue culture. Plant Sci. 170:1185-1190.

Puchooa, D. 2004. Comparison of different culture media for the in vitro culture of Dendrobium (Orchidaceae). Intl. J. Agr. Biol. 6:884-888.

Sittisuanjik, K. and K. Sriruksa. 2013. Comparative study on antioxidant activity, total phenolic contents and physicochemical properties of banana flours. Agr. Sci. J. 44(Suppl.):213-216 (in Thai).

Sripathumrak, P. 2004. Relationship between sugar content and glycemic index of Thai fruits. MS Thesis, Chulalongkorn Univ., Bangkok, Thailand (in Thai).

Tantasawat, P., A. Wannajindaporn, C. Chantawaree, C. Wangpunga, K. Poomsom, and A. Sorntip. 2010. Chitosan stimulates growth of micropropagated Dendrobium plantlets. Acta Hort. 878:205-212.

Tantasawat, P. and A. Waranyuwat. 2008. Plant tissue culture laboratory. Agentex, Bangkok, Thailand (in Thai).

Teixeira da Silva, J.A. 2013a. Orchids: Advances in tissue culture, genetics, phytochemistry and transgenic biotechnology. Floricult. Ornamental Biotechnol. 7:1-52.

Teixeira da Silva, J.A. 2013b. Impact of paper bridges, activated charcoal, and antioxidants on growth and development of protocorm-like bodies of hybrid Cymbidium. In Vitro Cell. Dev. Biol. Plant 49:414-420.

Thorpe, T., C. Stasolla, E.C. Yeung, G.J. De Klerk, A. Roberts, and E.F. George. 2008. The components of plant tissue culture media II: Organic additions, osmotic and $\mathrm{pH}$ effects, and support system, p. 115-173. In: E.F. George, M.A. Hall, and G.-J. De Klerk (eds.). Plant propagation by tissue culture. 3rd ed. Springer-Verlag, Dordrecht, The Netherlands.

Tokuhara, K. and M. Mii. 2003. Highlyefficient somatic embryogenesis from cell suspension cultures of Phalaenopsis orchids by adjusting carbohydrate sources. In Vitro Cell. Dev. Biol. Plant 39:635639.

Vacin, E.F. and F.W. Went. 1949. Some $\mathrm{pH}$ changes in nutrient solution. Bot. Gaz. 110:605-613.

Zhao, D., G. Hu, Z. Chen, Y. Shi, L. Zheng, A. Tang, and C. Long. 2013. Micropropagation and in vitro flowering of Dendrobium wangliangii: A critically endangered medicinal orchid. J. Medicinal Plants Res. 7:2098-2110. 